\title{
RE-INFECTION OR SUPER-INFECTION IN NEUROSYPHILIS
}

By A. O. F. ROSS, M.D., D.P.H., Senior Clinical Venereal Diseases Officer, City and Port of Liverpool ; Lecturer in Specific Diseases, University of Liverpool.

KopP AND Solomon (I939) in reporting a case of re-infection with syphilis in a neurosyphilitic, cite the statements of (a) Halley and Wassermann that in all of the suspected cases of re-infection with syphilis, from I9Io to I927, there was no record of an undoubted re-infection in any patient who had developed neurosyphilis as a result of his first infection, and $(b)$ Klauder and Butterworth, who reported a case of chancre redux in a neurosyphilitic I7 years after infection. No blood examination had been performed during that time. Kopp and Solomon also summarise a case reported by Tobias, which he rejected as a re-infection since Stokes's 2nd and r6th postulates were not observed and treatment, $a b$ initio, was insufficient. The work of Jahnel and Strempel on the non-susceptibility of the skin to react to spirochæte inoculation in serologically cured paretics, is also quoted.

In the case reported by Kopp and Solomon, the first infection occurred in I926, and was irregularly treated by the alternating system. The patient responded badly, developed a syphilitic meningitis, and later, while under active treatment by neo-arsphenamine, showed a cutaneous relapse. The C.S.F. was extremely refractory to treatment, and at no time became normal, although the Wassermann became negative and remained so. Treatment was continued from I926 till I934 fairly regularly, and then at intervals by bismuth alone till $3 / 7 / 37$. The last positive Wassermann was obtained on $1 / 10 / 29$, but an occasional doubtful result appeared until $8 / \mathrm{II} / 3 \mathrm{I}$. Hinton tests were negative, except for one doubtful reaction on $I / / / / 36$, until $3 / 7 / 37$.

On 25th September, I937, a penile lesion developed on a different site from the original lesion of I926. Spirochætes were found in this lesion, but. no immediate 


\section{INFECTION IN NEUROSYPHILIS}

regional lymphadenopathy developed. Exposure had occurred 2I and 3I days previously. The Hinton and Wassermann tests were both positive. No secondaries developed, and mapharside $0.02 \mathrm{gm}$. and bismuth salicylate $0.15 \mathrm{gm}$. were given on $30 / \mathrm{Io} / 37$. One week later, a second penile lesion developed in which spirochætes were found even after $0.09 \mathrm{gm}$. mapharside and $0.45 \mathrm{gm}$. bismuth salicylate had been given in I4 days. Inguinal and epitrochlear glands became enlarged on the IIth December, I937, while the patient was receiving weekly doses of mapharside and bismuth salicylate, and general lymphadenopathy was reported on I2th January, 1938. The C.F.S. showed excess globulin, but was otherwise normal. The Wassermann was reported as positive on $2 / 1 / 38$, but thereafter became negative. The Hinton test was still positive on $30 / 7 / 38$. The patient was difficult to treat since he had experienced nitritoid crises with both neo-arsphenamine and tryparsamide, and had had mercurial stomatitis.

This case is not altogether convincing, because of the development of a second chancre 42 days after the first, the delay in regional lymphadenopathy till 77 days after the appearance of the first chancre of the second attack, and the fact that since the Hinton and Wassermann tests were positive at the first test, no sero-negative primary stage was proved to have existed. In addition, the previous history showed that both clinical and serological relapse occurred, and the C.S.F. never became absolutely normal after the initial infection of 1926.

While one hesitates to claim that, at last, there is undoubted evidence that a patient who has developed neurosyphilis can be re-infected, the following history and report on a case, who was not treated for his original infection at one's own clinic until tabes dorsalis had developed, nor for the second infection until it was too late to satisfy the thirteenth and fourteenth postulates of Stokes, must challenge seriously the correctness of the established belief.

G.M., a seaman, aged 30 years, reported at the Seamen's Dispensary, Liverpool on $18 / 6 / 28$, complaining of acute gonorrhœa. He gave no history of syphilis, and his blood Wassermann, both at the beginning and the end of treatment, was negative.

In I932, he returned with a fresh attack of gonorrhœa, v.D. 


\section{BRITISH JOURNAL OF VENEREAL DISEASES}

and his blood Wassermann was again negative, but he complained of root pains and, on further enquiry, admitted infection with syphilis in I924, for which he had been treated by six intravenous and six intramuscular injections. Neurological examination showed early tabes dorsalis, with the findings:-

Pupils unequal, dilated, react to light and accommodation. Knee and ankle jerks absent. Vibration sense absent. Slight Rombergism. Analgesia along outer border of both feet. No cardio-aortic disease found.

The Wassermann of the cerebro-spinal fluid was positive in 0.5 c.c., and 0.25 c.c., but negative in 0.1 c.c. and 0.05 c.c. Protein, cells and Lange curve were normal.

A course of $24 \mathrm{gm}$. of tryparsamide was succeeded by I2 rigors of malarial therapy, and treatment by tryparsamide, neo-silversalvarsan and bismuth was given at intervals until 1938. In that year the cerebro-spinal fluid was completely normal, and the blood Wassermann negative.

In November, I939, the patient returned bearing a transfer card from Ellis Island. The details showed that one month after coitus in August, an ulcer in the left para-frænal region yielded Spirochata pallida, and inguinal lymphadenopathy was present. The Wassermann was anti-complementary, but the Kahn was negative on three occasions; $\mathrm{I} \cdot 95 \mathrm{gm}$. of neo-arsphenamine and $0.6 \mathrm{gm}$. of bismuth had been given.

The Wassermann and Meinicke tests, taken at the Seamen's Dispensary, were negative, and the cerebrospinal fluid was normal to all tests.

The neurological condition had improved, as evidenced by the following details : Pupils normal, equal and react to light and accommodation. Right knee jerk, slight but definite response. Left knee and ankle jerks, absent. Vibration sense, faint in left tibial region; absent in right tibial region. No Rombergism. No areas of analgesia.

Application was made to the clinic at which the patient received treatment in 1924 , but unfortunately no trace of the records could be found. The patient stated that his original ulcer was situated on the dorsal aspect of the balano-præputial fold.

From the information available, one is thus able to I72 


\section{INFECTION IN NEUROSYPHILIS}

relate this case to Stokes' (I934) I7 postulates' of reinfection.

I. First infection proved by blood Wassermann reaction or darkfield.-Tabes Dorsalis in I932. History of penile sore and treatment by neo-arsphenamine and bismuth in I924.

2. Negative physical examination two years after treatment.-Negative physical examination in I928-four years after infection and treatment.

3. Negative blood Wassermann for one year after treatment.-Blood Wassermann never positive while under observation from 1928 to I940.

4. Negative spinal fluid at end of treatment.-Cerebrospinal fluid completely negative I938 and I939.

5. No relapse between infections. - No relapse of visceral syphilis. Tabes non-progressive, and in fact, less evident.

6. Definite exposure history for second infection.-Brazil, August, I939.

7. Infectious source for second infection.-See 6!! Prostitute, inmate of brothel.

8. Normal incubation period for second chancre ( 7 to 40 days).-About 25 days.

9. Second chancre in different site and lymph drainage from first.-First chancre on mid-dorsum balano-præputial fold. Second chancre left parafrænal region, in sulcus.

Io. No activity at site of first chancre.-Apparently not. (Patient's statement and clinical notes from Ellis Island).

II. Positive darkfield, second chancre.-Yes.

i2. Satellite lymphadenopathy second chancre.-Yes.

13. Blood Wassermann reaction of second infection, negative at first, must change to positive.-Blood Wassermann, serum anti-complementary. Kahn on three occasions negative. Treatment by neo-arsphenamine and bismuth given, and thus Wassermann and Kahn inhibited in their development.

I4. Secondary eruption must appear not less than twenty days after second chancre.-Inhibited by treatment.

5. Treatment of first infection must approximate 20 arsphenamine injections and 20 bismuth or mercury injections. - Tabes developed owing to insufficient early treatment, but later treatment over five years caused clinical recession, and rendered C.S.F. negative.

16. Time interval between first and second infection must be two years or more.-Fifteen years. 


\section{BRITISH JOURNAL OF VENEREAL DISEASES}

I7. Competent observation must be had in both infections. -Apparently.

\section{SUMmARY}

The history and essential details are presented of a case of neurosyphilis (tabes dorsalis), who was re-infected with syphilis fifteen years after his original infection.

1924. Primary syphilis treated by six injections of "9I4" and bismuth.

I928. Serum Wassermann, negative.

I932. Serum Wassermann, negative. C.S.F. Wassermann, positive in 0.5 c.c. and 0.25 c.c., negative below, ; protein, cells, gold curve, normal. Signs and symptoms of tabes dorsalis. Treatment by tryparsamide, bismuth, neo-silversalvarsan and malaria. Total dosage, I932 to I937, tryparsamide, I50 g. ; neo-silversalvarsan, $2 \cdot 2$ g. ; bismuth, $2 \cdot 4 \mathrm{~g}$.

I938. C.S.F. and serum Wassermann, negative.

1939. Re-infection with syphilis. Spirochata pallida present in primary ulcer. Serum Wassermann, anti-complementary. Kahn, negative. C.S.F. Wassermann, negative; protein, cells and gold curve, normal.

\section{REFERENCES}

Kopp, I. \& Solomon, H. C. (I939) Amer. J. Syph., 23, 54.

STokes, J. H. (1934) “ Modern Clinical Syphilology,” London. W. B. Saunders, 2nd Ed., p. 233. 